\title{
Rehumanizing Education: Teaching and Learning as Co-Constructed Reflexive Praxis
}

\author{
Ellyn Lyle and Chantelle Caissie
}

\begin{abstract}
Teaching and learning are profoundly personal experiences, yet systems of education often prioritize ubiquitous agendas that alienate rather than engage. Creating space for individuals and their lived experiences has the capacity to transform the classroom from a place of containment to one of expansiveness. Resisting the tendency of education to think dichotomously about teaching/learning, theory/practice, and self/other, we engage here as two learners who happen to have shared a graduate program, one as teacher and one as student. Influenced by post-qualitative inquiry (St. Pierre, 2017a; St. Pierre, 2017b) and post academic writing (Badley, 2019), we engage reflexively to consider the experience of this shared learning journey.
\end{abstract}

\section{Context}

Teaching and learning are profoundly personal experiences, yet systems of education often prioritize ubiquitous agendas that alienate rather than engage. Beginning from a place that recognizes the inherently subjective entanglements that come with constructing knowledge (Bochner, 1997; Bochner \& Ellis, 2016; Clandinin, 2015; Connelly \& Clandinin, 2000; O'Grady et al., 2018; Palmer, 1993, 1997, 1998, 2004, 2017), we revisit the experience of our shared learning journey. We begin from our individual entry points and move through the ebb and flow of reflexivity as we explore practices that nurture both the individual and the collective. As we approach the conclusion of this shared journey, we consider possibilities for a re/humanization of education that positions teaching and learning and co-constructed reflexive praxis.

\section{Ellyn's Entry Point}

An island girl -

an island

in between

two sisters and two bodies -

of water -

of a farmer and a teacher

a creature of the land

guided by relationality

and responsibility

to place - 
to each other -

intimately aware

how we effect

and inform

crafted from red soil

sustained by saltwater

yet traded fields

of rippling barley and blossoming potatoes

for the field of education

with the exchange,

a promise -

to grow a praxis guided

by lessons on the land.

\section{Chantelle's Entry Point}

Cracked beneath the weight of my own conditioning.

I cautiously walk, trembling towards the unknown with the fragments of a broken heart stored beneath the lid of a warped

and dusty shoe box.

I emerge,

a voiceless learner,

a wannabe scholar,

a skilfully skill-less educator.

without warning,

I begin to run.

painfully vulnerable,

and stripped of my armour,

I run fearlessly,

towards the field of education

breaking free from a world of intellect,

towards a praxis of vulnerability

with only my broken heart,

and a dusty shoe box.

Our individual entry points intersect at a collective aim - the reflexive exploration of teaching and learning practices that are undergirded by lived experience. As such, we are firmly situated, both pedagogically and practically, in a place that acknowledges the constructivist and integrated nature of both teaching and learning (Clandinin, 2015). We are guided by the belief that each of us comes to learning with varied experiences that inform not only what we know, but also how we know. Despite 
these deeply human entanglements that characterize teaching and learning, much of education continues to prioritize dehumanized, decontextualized, and disembodied ways of knowing. Resisting this trend, pockets of educators have moved toward social constructivist conceptualizations of knowledge, which have, in turn, led to the rise of pedagogical approaches that resist monologic telling in favour of dialogic co-inquiry (Grimmett, 2016). Theoretically influenced by the work of scholars who advocate for co-construction of meaning (see, for example, the work of Dewey, Bakhtin, Freire, and Shor), dialogic pedagogies embrace a fluid and reflexive approach to meaning making (Edwards-Groves et al., 2014). Within this approach, knowledge is positioned as intensely personal and transient, all the while being negotiated within sociopolitical contexts (Grimmett, 2016). This impermanence of knowledge is a great equalizer in education as the teacher is no longer assumed to be the expert. Rather, each of us is respected as the authority on our own lives and agents of our negotiated understandings. This bringing together of self and society is inherently reflexive, as it requires us to look inward and outward in tandem as we struggle to make sense of the world and ourselves in it. By encouraging critical introspection of self in relationship with social context, reflexivity insists that we take responsibility for our perspectives and actions within a relational system (Oliver, 2004). In making this accountability central, reflexive approaches interrogate agency while probing philosophical notions about the nature of knowledge. By its very design, then, reflexivity disrupts normalized assumptions about how we come to knowledge, and presents essential questions about our capacity to account for our evolving understanding of lived experience (Cunliffe, 2016; Lyle, 2017). Reflexivity is not to be engaged casually. To be reflexive is to live with an empathic heart and redirect the onus of responsibility from $i$ to we with the intent of fostering deeper debate and critical questioning (Brookfield, 2017; Cunliffe, 2016).

Successfully facilitating such a pedagogical shift requires a personal willingness to extend the boundaries of our own comfort zones. Even as we acknowledge the important foundational work in landscapes of teacher professional knowledge that created the fertile ground on which these new conversations could grow (see, for example, Clandinin \& Connelly, 1996; Connelly \& Clandinin, 2000), we find ourselves drawn to Elizabeth St. Pierre's work advancing post-qualitative inquiry (PQI), specifically that which challenges conventional qualitative inquiry (2017a, 2017b, 2018). PQI resists methodological enclosure. In its refusal to be contained by empiricism, it emerges at/tending to the strange and deeply intimate ontological aspects of living in real time (St. Pierre, 2018, 2019). PQI is always becoming. It does not arrive completed, having followed step-by-step instructions, and it cannot be measured (St. Pierre, 2018, 2019). Rather, this experimental inquiry evades the structured and conceptual order of conventional research, enabling inquirers to follow rhizomatic pathways toward a world of living that draws focus "not on things already made, but on things in the making" (St. Pierre, 2018, p. 604). Shifting away from the traditional landscapes of insights lost within parenthetic references, she advocates for the unpredictable and seemingly organic spirit of writing (St. Pierre, 2018).

Drawing on these unpredictable encounters with the organic forces of PQI, Elizabeth St. Pierre's (2019) advocacy for all forms of writing as inherently epistemological led us to the scholarship of Graham Badley (2017, 2019, 2020a, 2020b) who champions post-academic writing. He maintains that, too often, as academic writers, we fail to extend ourselves beyond objectivity and, as a result, we litter our pages with 
academic jargon that no one understands, pulled from a place that no one can relate to, and where the author has simply disappeared (Badley, 2019). As self-expressive beings, we acknowledge that writing carves a new pathway that dares us to take risks and to welcome new adventures in thought (Badley, 2020a).

As a framework, PQI begins wherever we find ourselves to be, and the conditions of its emergence enable the opportunity to re/connect and re/construct new pathways of knowing (St. Pierre, 2019). The fluid and intimate nature of PQI provides a strong foundation to explore the raw and vulnerable spaces of human being. Situated, then, in post-qualitative inquiry and challenging the inaccessibility of traditional academic writing, we engage poetry to explore pathways to wholeness in our teaching and learning lives. Without a particular destination in mind, we consider how poetry can help us access things deeply held that might otherwise be inaccessible (Wiebe, 2015).

\section{Poetic Un/Certainty: Emerging Conversations With the Text and Each Other}

Sean Wiebe (2015) tells us that poetic inquiry enables the richness of lived experience to be shared in "fierce, tender, and mischievous" ways (p. 152)—ways unimpeded by academic traditions of proving. Instead, poetic inquiry encourages us to explore "meaning in living and being" (p. 153). Engaging poetically in the context of academic study is also engaging autobiographically, a channel through which Maxine Greene (1995) says we can achieve "freedom in an expanded sphere" and "act...to transform...what alienates people from themselves" (p. 27). But such expanded spheres require courage to navigate the inevitable vulnerability (Lyle, 2018; Lessard et al., 2018; Snowber \& Wiebe, 2009). Acknowledging that, "poetry reaches out to and from the human heart, embodying through artistic form what it means to be alive," we must be prepared for inquiry that "pulls us out in brave ways" (Finn, 2015, p. 5). As our conversations with each other and the texts continue to emerge, we notice two recurring themes as we endeavour to re/introduce humanness to teaching and learning: vulnerability and relationality.

\section{Vulnerability}

Vulnerability is an emotional risk that leaves us feeling exposed as we are pulled beyond our comfort zones. One of the most widely accepted myths is that vulnerability correlates with weakness. Society has weaved together a dangerous and collective denial of vulnerability, associating it with shame and disappointment (Brown, 2012; Finn, 2015). Teaching and learning, though, are acts of vulnerability because we project the condition of our souls onto each other, as the complexities of who we are become entangled in our subject and ways of being together (Lessard et al., 2018; Palmer, 2017).

Sarah MacKenzie (2012) maintains that learning is autobiographical, situated in our experiences, and central to shaping our perspectives of self, others, and the world. Our experiences, though, are often regarded as unreliable and hopelessly subjective within the sphere of academia. Parker Palmer (2017) states that, as educators conditioned to minimize vulnerability, we often take shelter in so-called 
objective ways of knowing. The silencing discourse of academia often closes the door on lived reality and forces us to compromise our experiences of [im]perfection for theoretical considerations and sterile language (Bochner, 1997; Clandinin et al., 2009; Thomas, 2018). M'Balia Thomas (2018) argues that within an "entrenched system of linguistic norms [and] unitary language" (p. 328), we never truly become acquainted with our whole being because we wrap ourselves in silence hoping to mask our vulnerability. Challenging academic giants who have prioritized these sterile ways of knowing is often regarded as academic suicide (Yoo, 2019), but we must resist academia's incessant need to separate our humanity from our work (Richardson, 1988).

Teaching and learning from a place that values lived experiences contributes to connection and mutual recognition of one another (Brookfield, 2017). However, taught to separate the personal and professional, we drag the roots of our failures and traumas to the depths of our unconscious minds. The failure to explore our humanity, then, alienates us from ourselves and misinforms our praxis. Vulnerability enables us to write what matters, at/tending to the constant and courageous emergence of who we are. Writing poetically creates room to find magic in the hurt and compassion in the chaos (Finn, 2015). Education does not need more standardized tools or assessments - it needs to learn how to be hospitable to the fragility and beauty of our vulnerability (Clandinin, 2015; Finn, 2015).

I've missed you.

I am so sorry,

I know I have been gone for a very long time.

I didn't know where to find you,

I was scared,

scared that maybe, maybe you didn't want to be found.

Do you remember me?

Do you need me,

Want me?

I know you're hurt,

I know you've been hurt.

I'm hurting too.

But maybe,

maybe we could hurt together?

— My inner child, I am so deeply sorry for your wounds.

Neither of us identifies as poets; however, in the midst of chaos and fear, words find us, easing our minds and slowly lulling us into a poetic understanding of how and who our beliefs and assumptions serve. Poetry offers a space to examine our experiences through words, creating a window into our thoughts that identifies the source of our attachments and fears (Faulkner, 2012; MacKenzie, 2019). The challenge 
of exposing our vulnerability often lies in the fear that accompanies it (Kenyon, 2019). The failure to acknowledge this fear, though, further contributes to disconnectedness (Kenyon, 2019; MacKenzie, 2019). As educators, we often enter the classroom with assumptions about how we think teachers and learners should behave; however, the complexities of culture, experience, politics, and consciousness that converge in teaching and learning often blur our perception of the effect we have on each other. We explore this effect as relationality.

\section{Relationality}

Celeste Snowber and Sean Wiebe (2009) refer to the body as home to living and breathing text, suggesting that the body offers invaluable insight into who we are and how we teach. So much of what we encounter throughout life — those experiences that write themselves on our being—we don't talk about (Snowber \& Wiebe, 2009). The adventurous style of writing dangerously (Yoo, 2019; Badley, 2020b) may appear provocative and reckless upon first glance; however, it enables us to inhabit its space, helping us see and hear the text, not from our minds, but from our hearts. Exploring the restricted section of self can break open the page and invite our vulnerability to exist in the company of others, connecting and commanding a communal transformation in learning and living (MacKenzie, 2019).

Writing is magic.

and no,

not the kind of magic you read in fantasy novels

or see in movies.

No, this magic awakens the soul.

You feel it in your bones.

Like lightening, it strikes you.

This magic had you sneaking out past curfew, driving through vacant parking lots.

This magic was found on track 4 of your cd mixtape,

windows down,

and volume on full blast.

This magic was found in the front seat of a broken-down station wagon singing, laughing, and crying with your best friend.

This magic was innocent,

Fearless,

Seventeen.

Writing is magic.

This magic held your gaze, inviting you into its warmth as it gently brushed your lips, intoxicating you with its kiss. 
This magic took you by the hand,

danced with you -

moved you to the melody of your heart.

This magic was love,

this magic was the one.

Writing is magic.

This magic screamed, manipulated -

brought every inch of you to the brink of fear.

This magic humiliated you,

left you bruised,

naked.

This magic had you triple checking that the doors were locked,

it had you sleeping with a night light on.

This magic -

this darkness -

was drowned with a stiff drink, or 10.

Writing is magic, you are magic.

Discomfort is inevitable in writing our teaching and learning lives and, often in the wake of our vulnerability, we feel alone in our unveiling. However, writing communicates, resonating with the rich complexities of life (Yoo, 2019). Writing ushers us toward real encounters with life, such as illness, violence, and death-encounters we may not have explored without writing. Through writing dangerously, we awaken our fears but, more importantly, we awaken our humanity. In her writing, Joanne Yoo (2019) offers reassurance, maintaining that the writer is already within each of us, prepared and willing to connect, if only we create the space. Writing and living poetically creates space for uncertainty and utilizes words as a springboard to foster connection and hope - it is through our vulnerability and relationality that we inspire and re/instill hope in our learners (MacKenzie, 2019).

Poetic inquiry offers a teaching and learning space that invites uncertainty and allows for creative exploration that fosters conscious awareness of how we come into being (MacKenzie, 2019). We write about our experiences and relationships in hope of gaining a sense of understanding that allows us to position education as a more liberating experience. Creating a brave space to invite our humanity to join us in our teaching and learning experiences enables a vulnerable interchange that breathes life back into curriculum (Snowber \& Wiebe, 2009). Ruth Behar (2009) explained that writing from a place of vulnerability attracts vulnerable readers who seek shelter from the intellectual world. Dangerous writers become our companions, then, and together we grow collectively, learning and reconstructing our lives from each other's words (Yoo, 2009). 


\section{Co-Constructed Praxis}

As teachers and learners, we are critical data sites, and our experiences offer a window into the behaviours and actions that contribute to education as a profoundly human endeavour. Engaging approaches to reflexive consciousness, like poetic inquiry, allows us to explore the inner terrain of self. At the heart of this approach is supporting learning as an evolving understanding in the context of relationship with others. Poetic writing offers an avenue that invites uncertainty and allows for creative exploration that fosters conscious awareness of how we come into being (MacKenzie, 2019). Poetry values the individual by examining our humanity from a holistic and ever-emerging lens. Through poetic writing, we become more resilient when confronted by traditional learning practices that perpetuate dehumanization. In living and learning, we crave connection; poetry constructs a space that permits multiple meanings to surface through language and fosters a sense of hope in the midst of uncertainty (MacKenzie, 2019).

Prioritizing and attending to the realities of our lives infuses our writing, learning, and teaching with warmth and authenticity (Badley, 2019). Breaking free from the scripted or sanitized versions of our lives unveils our [im]perfect being, crafted by experiences and seasoned with stories that expose the nature of teaching and learning (Harkins et al., 2009). Operating beyond linguistic borders creates a space to playfully re/negotiate text, extending our voices to the ears of the majority, demanding they listen to what we have to say (Thomas, 2018). It is through experimentation that we encounter authentic voice. Our capacity to engage in difficult or dangerous writing challenges the often-inaccessible language of academia (Badley, 2020a).

We acknowledge that this way of being is both personal and political as it stands to resist dehumanized systems of schooling in favour of claiming education as a space where critical and reflexive practices can drive social change. To achieve this goal, we endeavour to engage in ways that are grounded in both individual and collective humanity with the intention of supporting relevant learning, such that the effect of education is felt long after students leave formal schooling.

Deconstructing teaching and learning through poetic inquiry has provided us with the space to identify the characteristics and assumptions that have structured and influenced our praxis. Freire (2005) argues, "only dialogue truly communicates" (p. 40), which speaks to the significance of creating healthy and reciprocal relationships within the classroom.

Words are like musical notes, each word represents a pitch a duration of sound.

Words, when played together, create harmony and depth.

Our words can be happy, upbeat, and playful to the soul

Or 
Romantic and gentle, as they tuck us in closer to their warmth on a chilly September night.

Or

Our words can be tragic, shattering our perception of the world and scaring the inner landscape of our innocence.

Our words correspond to the song playing in our hearts.

\section{In/Conclusion}

As educators, we are not solely responsible for creating a safe space for our learners; we are also responsible for creating a safe space for ourselves. Embracing humanity within a learning space invites dialogue and extends an opportunity for individuals to speak a new language of creativity and knowing beyond a world of objectivity (Bochner, 1997; Lyle, 2018). Our experiences provide a window of opportunity to become re/acquainted with the new and changing seasons of our lives. Often as educators, we become disenchanted as systemic hegemony works to impede our efforts to re/negotiate or re/form our practices (Duenkel et al., 2014; Palmer, 2017). The ability not only to cultivate new perspectives, but also to act upon new-found insights, is a necessary constituent of transformative learning among current and prospective educators (Liu, 2015). Embracing the fragmented pieces or broken paradoxes that have framed our perceptions of self and others, fosters creative space for existing narratives to become dismantled or rewritten (Lyle, 2018).

Writing/living/teaching/learning poetically has provided a safe and creative space for us to begin unravelling the critical and fragile aspects of our humanity. We maintain that nurturing a trusting relationship between the student and teacher does not begin until we learn how to trust ourselves. With/in this space resides a gentle but unrelenting call to resist the dominant discourse that would write our stories for us.

Own your story -

take all the broken shards

and assemble them

with your trembling hands, piece by piece,

gaining confidence

in the reconstitution

of you.

Whole once more, polish yourself to a shine

that illuminates

all those around you

so that they cannot

help but to see.

- transcendence

LEARNing Landscapes | Spring 2021, Vol. 14 No. 1 | 227 


\section{References}

Badley, G. F. (2017). Composing academic identities: Stories that matter? Qualitative Inquiry, 22(5), 377-385. https://doi.org/10.1177/1077800415615845

Badley, G. (2019) Post-academic writing: Human writing for human readers. Qualitative Inquiry, 25(2), 180-191.

Badley, G. (2020a) How and why academic write. Qualitative Inquiry, 26(3-4), 247-256.

Badley, G. (2020b). We must write dangerously. Qualitative Inquiry, 1-7.

Behar, R. (2009). Believing in anthropology as literature. In A. Waterston \& M. D. Vesperi (Eds.), Anthropology off the shelf: Anthropologists on writing (pp. 106-116). Wiley-Blackwell.

Bochner, A. (1997). It's about time: Narrative and the divided self. Qualitative Inquiry, 3(4), 418-438.

Bochner, A., \& Ellis, C. (2016). Evocative autoethnography: Writing life and telling stories. Taylor and Francis.

Brookfield, S. (2017). Becoming a critically reflective teacher. Jossey-Bass.

Brown, B. (2012). Daring greatly: How the courage to be vulnerable transforms the way we live, love, parent, and lead. Penguin Group, Gotham Books.

Clandinin, D. J. (2015). Stories to live by on the professional knowledge landscape. Waikato Journal of Education (2382-0373), 183-193.

Clandinin, D. J., \& Connelly, F. M. (1996). Teachers' professional knowledge landscapes: Teacher stories-stories of teachers-school stories—stories of schools. Educational Researcher, 25(3), 24-30. https://doi.org/10.3102/0013189X025003024

Clandinin, D. J., Downey, C. A., \& Huber, J. (2009). Attending to changing landscapes: Shaping the interwoven identities of teachers and teacher educators. Asia-Pacific Journal of Teacher Education, 37(2), 141-154. https://doi.org/10.1080/13598660902806316

Connelly, F. M., \& Clandinin, D. J. (2000). Narrative understandings of teacher knowledge. Journal of Curriculum \& Supervision, 15(4), 315-331.

Cunliffe, A. L. (2016). "On becoming a critically reflexive practitioners" redux: What does it mean to be reflexive. Journal of Management Education, 40(6), 740-746. http://doi:10.1177/1052562916668919

Duenkel, N., Pratt, J., \& Sullivan, J. (2014). Seeking wholeheartedness in education: Power, hegemony, and transformation. Journal of Transformative Education, 12(3), 266-291. https://journals-sagepubcom.libraryservices.yorkvilleu.ca/doi/full/10.1177/1541344614543192

Edwards-Groves, C., Anstey, M., \& Bull, G. (2014). Classroom talk: Understanding dialogue, pedagogy and practice. PETAA.

Faulkner, S. (2012). Frogging it: A poetic analysis of relationship dissolution. Qualitative Research in Education, 1(2), 202-227. 
Rehumanizing Education: Teaching and Learning as Co-Constructed Reflexive Praxis

Finn, J. (2015). An artist's experience of exploring her creative edge. Journal of Sustainability Education, 9, 1-15. http://www.jsedimensions.org/wordpress/wp-content/uploads/2015/03/Finn-JSE-March-2015Love-Issue.pdf

Freire, P. (1994/2005). Education for critical consciousness (pp. 37-51). Education and Conscientizaco. Continuum.

Greene, M. (1995). Releasing the imagination: Essays on education, the arts, and social change. Jossey-Bass.

Grimmett, H. (2016). The problem of just tell us: Insights from playing with poetic inquiry and dialogic self theory. Studying Teacher Education, 12(1), 37-54. Routledge.

http://dx.doi.org/10.1080/17425964.2016.1143810

Harkins, M., Forrest, M., \& Keener, T. (2009). Room for fear: Using our own personal stories in teacher education. Journal of Teaching and Learning, 6(1), 15-23.

Kenyon, E. (2019). Negotiating fear and whiteness. In E. Lyle (Ed.), Fostering a relational pedagogy: Self-study as transformative praxis (pp. 71-81). Brill | Sense.

Lessard, S., Caine, V., \& Clandinin, D. J. (2018). Exploring neglected narratives: Understanding vulnerability in narrative inquiry. Irish Educational Studies, 37(2), 191.

Liu, K. (2015). Critical reflection as a framework for transformational learning in teacher education. Educational Review, 67(2), 135-157. https://search-ebscohost-

com.libraryservices.yorkvilleu.ca/login.aspx?direct=true\&AuthType=url,cookie,ip, uid\&db=a9h\&AN=101018113

Lyle, E. (2017). Of books, barns, and boardrooms: Exploring praxis through reflexive inquiry. Sense.

Lyle, E. (2018). Possible selves: Restor(y)ing wholeness through autobiography. LEARNing Landscapes, 11(2), 255-268.

MacKenzie, S. (2012). Poetic praxis: Engaging body, mind, and soul in the social foundations classroom. Journal for Learning Through the Arts, 9(1), 1-27.

MacKenzie, S. (2019). (Re)acquaintance with praxis: A poetic inquiry into shame, sobriety, and the case for a curriculum of authenticity. Journal of Curriculum Theorizing, 34, 72-89.

O'Grady, G., Clandinin, D. J., \& O'Toole, J. (2018). Engaging in educational narrative inquiry:

Making visible alternative knowledge. Irish Educational Studies, 37(2), 153-157.

https://doi.org/10.1080/03323315.2018.1475149

Oliver, C. (2004). Reflexive inquiry and the strange loop tool. Journal of Systemic Consultation and Management, 15(2), 127-140.

Palmer, P. (1993). To know as we are known. Harper Collins.

Palmer, P. (1997). The heart of a teacher: Identity and integrity in teaching. Change, 29, 6, 14-21.

Palmer, P. (1998). The courage to teach. Jossey-Bass.

Palmer, P. (2004). A hidden wholeness: The journey toward an undivided life. Jossey-Bass.

Palmer, P. (2017). The courage to teach. Jossey-Bass. 
Richardson, L. (1988). The collective story: Postmodernism and the writing of sociology. Sociological Focus, 21(3), 199-208. https://doi.org/10.1080/00380237.1988.10570978

Snowber, C., \& Wiebe, S. (2009). In praise of the vulnerable: A poetic and autobiographical response to Salvio's abundant Sexton. Journal of the American Association for the Advancement of Curriculum Studies, 5(1), 1-18.

St. Pierre, E. (2017a). Writing post-qualitative inquiry. Qualitative Inquiry, 0, 00, 1-6.

St. Pierre, E. (2017b). Haecceity: Laying out a plane for post qualitative inquiry. Qualitative Inquiry, 23(9), 686-698.

St. Pierre, E. A. (2018). Writing post qualitative inquiry. Qualitative Inquiry, 24(9), 603-608. https://doi.org/10.1177/1077800417734567

St. Pierre, E. A. (2019). Post qualitative inquiry in an ontology of immanence. Qualitative Inquiry, 25(1), 3-16. https://doi.org/10.1177/1077800418772634

Thomas, M. (2018). The girl who lived: Exploring the liminal spaces of self-study research with textual critical partners. In D. Garbett \& A. Ovens (Eds.), Pushing boundaries and crossing borders: Self-study as a means for knowing pedagogy (pp. 327-333). S-STEP.

Wiebe, S. (2015). Poetic inquiry: A fierce, tender, and mischievous relationship with lived experience. Language and Literacy, 17(3), 152-163.

Yoo, J. (2019). A year of writing 'dangerously': A narrative of hope. New Writing, 16(3), 353-362. https://doi.org.10.1080/14790726.2018.1520893

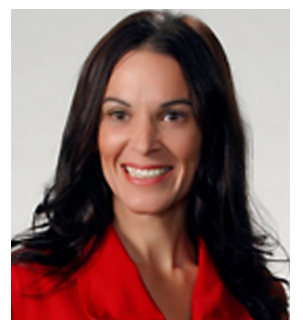

Ellyn Lyle is an avid gardener and ardent reader of life and lived experience. Intensely interested in creating spaces for learners to engage meaningfully with their studies, she is drawn to inquiries that seek to overcome compartmentalized, fragmented, and dehumanized approaches to education. Having joined the academic community full time in 2011, she is currently Dean in the Faculty of Education at Yorkville University. The use of critical and reflexive methodologies shape explorations within the following areas: intersections of self and subject and their implications for teacher and learner identity; praxis and practitioner development; lived and living curriculum; and undivided ways of knowing and being.

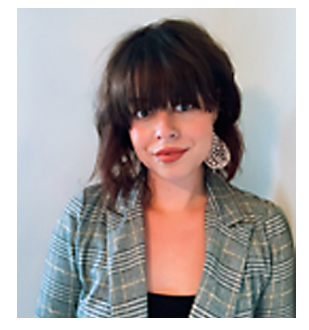

Chantelle Caissie, an Alumna at Yorkville University, has a rich and diverse background in health and community services, with a Bachelor of Arts Degree in Psychology and a Graduate Certificate in Addictions \& Mental Health Counselling. Her compassion for marginalized populations and advocacy for social justice led her toward achieving a Master's Degree in Education, specializing in Adult Education. As a health professional transitioning into the education sector, Chantelle has challenged dominant academic discourse, hoping to encourage a shift away from objectivity toward exploring the tender and vulnerable spaces of our interior lives imperative to our growth as both working professionals and human beings being. 